\title{
ACCESS TO A LAWYER IN PROCEEDINGS FOR MINOR OFFENCES UNDER POLISH AND EUROPEAN UNION LAW
}

\author{
Iwona Bień Wegtowska*
}

\begin{abstract}
The Article deals with the opportunity for a suspected person and the passive party in the proceedings for offences to exercise the right of access to a lawyer and the right of legal counsel. The aim of the article is to provide a comparative legal analysis of the provisions of the Code of Procedure in Minor Offences against the background of the EU guarantees under Directives 2013/48/EU and 2016/1919/ EU. Directive 2013/48/EU deals with one of the two aspects of the aforementioned right: namely the right of access to a lawyer for suspects and accused persons in criminal proceedings, while the right to legal aid and to state-guaranteed legal assistance in certain circumstances is regulated by Directive 2016/1919/EU.
\end{abstract}

Key words: access to a lawyer, right of defence, Directive 2013/48/EU, ex officio defence counsel, Directive 2016/1919/EU

\section{INTRODUCTION}

The right of defence is one of the most important guarantees of a modern criminal trial, the essence of which is to ensure that the accused is able to defend himself or herself and to use the assistance of a defence

\footnotetext{
* PhD, Iwona Bień-Węgłowska, Associate Professor at the Department of Criminal Procedure, Faculty of Law, Canon Law and Administration, John Paul II Catholic University of Lublin, Al. Racławickie 14, 20-950 Lublin, Poland; e-mail: iweglowska@kul.pl; https://orcid.org/0000-0002-8575-8085.
} 
counsel. In its formal aspect, the right of defence constitutes a prerequisite for the exercise of the right to a fair trial. In this context, the moment when the right to defence counsel is activated is important. The close link between access to defence counsel and the right of defence justifies why at the EU-level minimum standards on the rights of individuals in criminal proceedings were established, along with rules for their application in Member States, with an intention to contribute to effective judicial cooperation in this area.

The aim of this article is to explore how an accused person in proceedings for minor offences can benefit from his or her right of defence. This primarily concerns access to a lawyer during both the investigative and the procedural stage. This article aims to assess if the regulations contained in Poland's legislative framework, covering all the stages in proceedings for minor offences, are consistent with the standards regulating the right of defence under EU regulations.

\section{ACCESS TO A LAWYER UNDER DIRECTIVE 2013/48/EU}

European Union law guarantees access to a lawyer for suspects and the accused in criminal proceedings in Directive 2013/48/EU of the European Parliament and of the Council on the right of access to a lawyer in criminal proceedings and European arrest warrant proceedings and on the right to communicate with third parties and consular authorities when deprived of liberty ${ }^{1}$. Directive 2013/48/EU was adopted on 22 October $^{2}$.

OJ L 294/1, 6.11. 2013.

2 The deadline for transposition of Directive 2013/48/EU into national law passed on 27 November 2016. By then, Member States should have brought into force the laws, regulations and administrative provisions necessary to comply with this Directive (Article 15(1) of Directive 2013/48/EU). The Ministry of Foreign Affairs, which is responsible for providing the European Commission with information on the state of implementation of EU acts into Polish law, has confirmed the conformity of Polish law with the Directive. See: Document 32013L0048: National transposition measures communicated by the Member States concerning Directive 2013/48/UE - https://eur-lex.europa.eu/legal-content/EN/NIM/?uri=celex:32013L0048. 
The purpose of this Directive is to establish common minimum standards concerning the rights of individuals in criminal proceedings ${ }^{3}$. Member States may extend the rights set out in the Directive in order to ensure a higher level of protection for the individual. However, the level of protection should never be lower than the standards laid down in the Charter of Fundamental Rights of the European Union and in the European Charter of Human Rights, as interpreted by the rulings of the Court of Justice of the EU and the European Court of Human Rights ${ }^{4}$. The Directive requires Member States to ensure that suspects and the accused have the right of access to a lawyer "[...] in such time and in such a manner so as to allow the persons concerned to exercise their rights of defence practically and efficiently." 5 .

\subsection{Scope of the Directive}

The Directive applies to criminal proceedings (except as indicated in Recital 13, i.e. it does not apply to proceedings for minor offences committed in prison or offences committed in the context of military service, dealt with by a relevant commander), as well as to the European arrest warrant proceedings.

The term "criminal proceedings" used in the Directive also includes proceedings before a court having jurisdiction in criminal matters with respect to minor offences. Where, under the law of a Member State, an authority other than a court having jurisdiction in criminal matters may impose a penalty for a "minor offence", but there is an appeal (Article 2(4)(a)) or it is not possible to impose a custodial sentence for it (Article 2(4)(b)), the Directive applies only at the stage of the proceedings before the court

3 Recital 4 of Directive 2013/48/EU.

4 Recital 7 of Directive 2013/48/EU.

Article 3(1) of Directive 2013/48/EU. The Directive uses the term "lawyer" which, according to Recital 15 , refers to any person who, in accordance with national law, is qualified and entitled (including by means of accreditation by an authorised body) to provide legal advice and assistance to suspects or accused persons. Under Polish law since 1 July 2015, analogical qualifications have also been bestowed on legal advisers and attorneys-at-law (barristers). However, for the purposes of this article the uniform concept of "lawyer" is used, which also includes legal advisers and attorneys-at-law (barristers, etc.). 
having jurisdiction in criminal matters. The way in which the Directive refers to "minor offences" indicates the need to apply it under Polish law also to the general category of offences. In practice, this means that the compatibility of the procedural guarantees contained in the Directive can be assessed in the light of the applicable provisions of Poland's Code of Criminal Procedure ${ }^{6}$ and the Code of Procedure for Minor Offences ${ }^{7}$. In view of the exemptions provided for in Article 2(4) of the Directive, the Directive should apply, either at the stage of legal proceedings only, in the case of offences for which a fine may be imposed by the police or other qualified authority by way of a criminal conviction (Article $2(4)(\mathrm{a})$ ) or for which there is no penalty for detention (Article 2(4)(b)), or in the course of investigations, in other cases ${ }^{8}$.

Recital 16 of the Directive makes it clear that, in the case of traffic offences committed on a large scale and detected following traffic control, the rights conferred by the Directive apply only to legal proceedings instituted by an appeal against a punishment imposed by a competent authority. Recital 17 states that the Directive should apply only to proceedings before a court having jurisdiction in criminal matters also in the case of offences involving violation of the general regulations issued by local authorities, as well as offences that involve violation of the public order for which deprivation of liberty cannot be adjudicated.

\subsection{Subjective scope of the Directive}

The Directive outlines the subjective scope of its application, i.e. who has the right of access to a lawyer and in what situations. In criminal proceedings, this right applies to suspects or the accused from the time when they are informed by the competent authorities by official notification, or otherwise, that they are suspected or accused of having committed a crim-

6 Act of 6 June 1997, the Code of Criminal Procedure, Journal of Laws of 2020, item 30

7 Act of 24 August 2001, Code of Procedure in Minor Offences, Journal of Laws of 2019, item 1120

8 See: A. Klamczyńska, T. Ostropolski, Prawo do adwokata w dyrektywie 2013/48/ UE - tło europejskie i implikacje dla polskiego ustawodawcy, Białostockie Studia Prawnicze 15 (2014), 154. 
inal offence, whether or not they are deprived of liberty9. The Directive also applies to persons who become suspects or are accused in the course of police or other law enforcement authority investigation ${ }^{10}$. It follows from Recital 21 of the Directive that the moment in the course of questioning when those persons are to be notified of a change in their status is when self-incrimination information occurs, since Recital 21 overtly refers to the right of protection against self-incrimination and the right to remain silent ${ }^{11}$. This situation may arise in the case of a witness whose status changes during the questioning, when he or she starts to provide self-incriminating information. A person acting as a witness may be questioned as a suspect but, in accordance with the guarantees of the Directive, this should only be done after having informed him or her of their rights, including the right of access to a lawyer ${ }^{12}$.

The right of access to a lawyer is therefore activated from the moment when a suspect or the accused is informed (whether by means of a formal charge or otherwise) of his or her procedural status. This person can use its right of access to a lawyer until the end of the proceedings, including all forms and stages of appeal ${ }^{13}$. Certain doubts can occur in the interpretation of alternative ways of notifying suspicion of a criminal offence - other than an official charge - which conditions activating the rights provided by the Directive. Explanations in this regard may be sought in the jurisprudence of the European Court of Human Rights (ECtHR judgment of 18.02.2010 in Zaichenko v. Russia, Application no. 39660/02). This judgment indicates that "accusation" means a formal notification of the charges, but it also implies a significant change in a person's procedural situation, e.g. at the time of his or her arrest or initiation of proceedings against him or her. It should be noted that the judgment concerns the concept of "accusation" to which Article 6 of the ECHR refers. Worthy of a note is also that the guarantees contained in the Directive under analysis reach beyond Article 6 of the ECHR (since the Directive includes

9 Article 2(1) of Directive 2013/48/EU.

10 Article 2(3) of Directive 2013/48/EU.

11 See: M. Wąsek-Wiaderek, Dostęp do adwokata na wczesnym etapie postępowania karnego w prawie Unii Europejskiej, Europejski Przegląd Sądowy 1 (2019), 18.

12 Recital 21 of Directive 2013/48/EU.

13 Article 2(1) of Directive 2013/48/EU. 
notification of a third party, communication with consular authorities in the event of deprivation of liberty, and the European arrest warrant proceedings). It must therefore be assumed that under the Directive, both the right of access to a lawyer (covered by Article 6 ECHR) and the other rights under the Directive are also activated when other actions indicating suspicion are taken against the person concerned $^{14}$, i.e. questioning by the police and other relevant authorities ${ }^{15}$, detention and provisional $\operatorname{arrest}^{16}$, identity parade, confrontation and reconstruction of the course of the event on the basis of procedural experiments ${ }^{17}$, as well as summons to appear before the court ${ }^{18}$. If a relevant authority takes any of these steps, the right of access to a lawyer is activated. However, it should be stressed that, according to Recital 20 of the Directive, its guarantees do not apply to so-called preliminary questioning by the police or other law enforcement authorities with the sole aim of establishing the identity of the person concerned or of clarifying safety issues, carrying out roadside checks and other random checks.

In proceedings for offences, activities related to establishing the identity of a given person undertaken by police officers concern identification of a person suspected of committing an offence, identification of witnesses of an event causing a violation of public safety or order, execution of an order issued by the court, prosecutor or government and local government administration bodies, as well as identification of persons indicated by wronged parties as perpetrators of offences. While verifying the identity of a given person in the course of procedural actions, police officers possess the right of constraining personal liberty to operate to the extent and for the time necessary to effectively establish the identity. Therefore, this type of action cannot be qualified as deprivation of liberty that would activate any kind of detention-related procedural regime. The legislator clearly distinguishes between the act of identity check and the act of police

\footnotetext{
14 See: A. Klamczyńska, T. Ostropolski, Prawo do adwokata..., 150.

15 Article 3(2)(a) of Directive 2013/48/EU.

16 Recital 14 of Directive 2013/48/EU.

17 Article 3(3)(c) of Directive 2013/48/EU.

18 Article 3(2)(d) of Directive 2013/48/EU.
} 
(e.g. in the case of public order violation) or other procedural detention ${ }^{19}$. Likewise, the provisions of Directive 2013/48/EU do not apply to activities aimed at establishing the identity of a person, as they treat these identification efforts only as measures analogical to questioning ${ }^{20}$.

Under Polish law, the guarantees contained in the Directive should therefore apply to a suspect who has been charged or questioned as a suspect without a prior decision to charge him or her ${ }^{21}$. Also, it should therefore apply to the accused ${ }^{22}$, but also to a person who is suspected of having committed a criminal offence - in other words, who is suspected of having committed it, but has not yet been charged ${ }^{23}$. Yet, this person can be lawfully involved in activities to confirm the suspicions of his or her having committed the act, or to exclude him or her from the list of potential perpetrators ${ }^{24}$. Referring to the provisions of the Directive, there should be no doubt that actions aimed at prosecuting a suspected person, which are outlined in the Directive, such as detention or identity parade (police line-up), result in the need to ensure his or her right of access to a lawyer, even if he or she has the procedural status of a suspected person rather than a suspect under Poland's national law ${ }^{25}$.

Since the Directive also applies to offences, the rights provided for in the Directive should be exercised by: (a) a person suspected of having committed an offence, who is subject to investigative measures, and who

19 See: Z. Gądzik, Komentarz do art. 15, In: Ustawa o Policji. Komentarz, Ł. Czebotar, Z. Gądzik, A. Łyżwa, A. Michałek, A. Świerczewska-Gąsiorowska, M. Tokarski, LEX/el. 2015, thesis 3.

20 See: M. Wąsek-Wiaderek, Dostęp do adwokata..., 18.

21 Article 71 par. 1, Article 325g of the Code of Criminal Procedure.

22 Article 71 par. 2 of the Code of Criminal Procedure.

23 The basic criteria distinguishing a suspected person are the lack of a formal element (presentation of charges) and the existence of a factual element, i.e. data at least justifying (to the degree of probability required to initiate proceedings in rem-Article 303 of the Code of Criminal Procedure), and at most sufficiently justifying the charges. In turn, the degree of probability of the factual element determines the nature of the action taken against a suspected person. See: K. Eichstaed, Komentarz do art. 71 k.p.k. In: Kodeks postępowania karnego, Tom I, Komentarz aktualizowany, ed. by D. Świecki, LEX/el. 2019, thesis 8.

${ }_{24}$ Article 74 par. 3 of the Code of Criminal Procedure. See: A. Klamczyńska, T. Ostropolski, Prawo do adwokata..., 155.

25 See: M. Wąsek-Wiaderek, Dostęp do adwokata..., 18. 
may be subject to certain evidentiary measures, as indicated in Article 74 par. 3 and 3a of the Code of Criminal Procedure, as well as Article 308 par. 1 of the Code of Criminal Procedure; ${ }^{26}$ (b) a person who can reasonably be presented with a request of punishment, and who may be questioned after being informed of the content of the charges entered in the minutes of the questioning ${ }^{27}$ - to the extent not covered by the exceptions specified in Article 2(4) of the Directive; and (c) the requested person - in practice a person against whom proceedings for offences are initiated and who has formally acquired the status of a party in the proceedings $\mathrm{s}^{28}$.

Analysing the subjective scope of the Directive and the degree to which they harmonise with the procedural guarantees outlined in Poland's Code of Procedure in Minor Offences, one needs to take into account first of all the procedural circumstances set out in the Directive, which determine the activation of the right of access to a lawyer, but not the terms and concepts that the Directive employs. It is important that the notion of a suspect used in Article 2(1) of the Directive has an autonomous meaning, independent of national legal systems. However, it is also legitimate to state that it must not deviate from the way in which the notion of a suspect is defined - also autonomously - in ECtHR case law, pursuant to Article 6 of the ECHR ${ }^{29}$. At this point, it should be stressed that Poland's Code of Procedure in Minor Offences does not use the term suspect at all. However, given the conditions which activate the right of access to a lawyer under the provisions of the Directive, the procedural guarantees bestowed on a suspect under the Directive should be addressed as the rights of a person specified in Article 54 par. 6 of the Code of Procedure in Minor Offences, as well as to a person suspected of committing an offence. Similarly, the guarantees for an accused person should be considered in the context of the rights of a requested person.

26 Article 54 par. 5 of the Code of Procedure in Minor Offences.

27 Article 54 par. 6 of the Code of Procedure in Minor Offences.

28 Article 20 par. 1 of the Code of Procedure in Minor Offences.

29 See: M. Wąsek-Wiaderek, Dostęp do adwokata..., 18. 


\section{NATIONAL PRACTICE AND APPLICATION OF EU LAW}

Each authority engaged in proceedings for offences is obliged to interpret the legal provisions in accordance with the Constitution of the Republic of Poland, i.e. to reject such an interpretation of the relevant provisions that would be in conflict with the wording or purpose of the constitutional regulations. Similarly, it is the duty of each authority applying the provisions of the Code of Procedure in Minor Offences to reject such an understanding of these provisions which would be in conflict with the regulations of the European Convention on Human Rights and the legislation of the European Union ${ }^{30}$. As regards the right of access to a lawyer, the interpretation of the provisions of the Code of Procedure in Minor Offences should therefore not contradict the provisions of Directive 2013/48/EU and Directive 2016/1919/EU.

\subsection{Suspect's right of access to a defence counsel}

Directive 2013/48/EU applies to the investigation phase of the proceedings for offences, on condition that the punishment imposed by the proceedings may consist of deprivation of liberty. It equally applies in any case of deprivation of liberty (detention) of the person suspected of committing an offence ${ }^{31}$.

The Directive guarantees access to a lawyer for the person suspected of committing an offence in connection with the procedural actions that may be carried out with his or her participation. Under these circumstances, the condition for the mandatory notification of the content of the charge does not apply, since the suspected person takes part in the proceedings for offences at its early stage, and it is only when certain evidentiary actions are carried out in his or her presence that the necessary grounds for the prosecution of the offence can be obtained and, consequently, a request of

30 See: A. Światłowski, Dział I. Zasady ogólne, art. 1, In: Kodeks postępowania w sprawach o wykroczenia. Komentarz, ed. by Andrzej Sakowicz, Warsaw: Wydawnictwo C.H. Beck, 2018, 9.

31 See: M. Wąsek-Wiaderek, Dział I. Zasady ogólne, art. 4, In: Kodeks postępowania w sprawach o wykroczenia..., 18. 
punishment can be issued. In the absence of sufficient grounds to justify the fact that that person may have committed an offence, he or she should not be questioned as a person with respect to whom there are reasonable grounds for issuing a request of punishment ${ }^{32}$.

Article 54 par. 5 of the Code of Procedure in Minor Offences indicates that the provisions of Article 74 par. 3 and $3 \mathrm{a}$ and Article 308 par. 1 of the Code of Criminal Procedure apply respectively to a person suspected of committing an offence. Pursuant to Article 74 par. 3 of the Code of Criminal Procedure, a suspected person may be subject to identity parade (police line-up). The person suspected of an offence must obligatorily be involved in this action. In this situation, the right of access to a lawyer during the identity parade, as layed down in Article 3(3)(c) of the Directive, is activated. This provision obliges Member States to ensure that suspects or accused persons can exercise their right to a lawyer and - at the minimum - to his presence during any investigative or evidence-gathering action provided for in national law. This provision also ensures presence of a lawyer if carrying out of a given procedural action requires or permits the participation of a person who is subject to the procedures of identity parade, confrontation and reconstruction of events ${ }^{33}$. At this point, it should be stressed that the provisions of the Code of Procedure in Minor Offences do not regulate at all the issue of the presence of a suspect's lawyer during the investigative actions with his or her participation.

A person detained under Article 46 of the Code of Procedure in Minor Offences should also enjoy the right of defence. This is because a detained person is sui generis accused of offence, who should enjoy his or her right of defence at the earliest stage of action against him or her ${ }^{34}$ : it is not a formal presentation of a charge, but the initial actions of the procedural bodies aimed at prosecuting a person that makes that person subject of his or her

32 See: T. Pączek, Pozycja prawna osoby podejrzanej o popełnienie wykroczenia w procesowym prawie wykroczeń, Policja 3 (2005), 45-46.

33 Rulings by ECtHR indicate a legal obligation to ensure access to a lawyer at an early stage of the proceedings in relation to the actions carried out by the authorised bodies, for instance, in the case of identity parade. See Mehmet Serif Öner v Turkey, Judgment of 13.09.2011, application No 50356/08.

34 See: J. Kosonoga, Dział VI, Środki przymusu, Rozdział 8, Zatrzymanie, Art. 46, In: Kodeks postępowania w sprawach o wykroczenia..., 275. 
right of defence ${ }^{35}$. Detention of a person in proceedings for an offence is regulated by Article 46 of the Code of Procedure in Minor Offences. This provision is a guarantee, since, according to paragraph 1 , a detained person must be informed immediately of the reasons for his or her detention and of his or her rights, and must be heard, which means that it is imperative to communicate that a law enforcement authority has a reasonable suspicion that he or she may have committed an offence. In this respect, the Code of Procedure in Minor Offences meets the condition for informing a suspicion of a criminal offence, as required by Article 2(1) of Directive 2013/48/EU.

The right of a detained person to communicate with a lawyer and to have a direct conversation with him or her is safeguarded by Article 46 par. 4, thus implementing the guarantees under Directive 2013/48/EU ${ }^{36}$ as far as the very rule of access to a lawyer is concerned, whereas a lawyer with whom a detained person has the right to communicate may not exercise his or her defence functions until the actions under Article 54 par. 6 of the Code of Procedure in Minor Offences have been under$\operatorname{taken}^{37}$. This latter provision is not in line with the requirements of the Directive, which, in Article 3(1), obliges Member States to ensure that suspects and accused persons have the right of access to a lawyer in such a way that they can effectively exercise their rights of defence. Also, under Article 3(2)(c), the right of access and defence should be activated immediately after deprivation of liberty ${ }^{38}$. Moreover, the way in which

35 See: Ruling of the Supreme Court of Poland of 9 February 2004, V KK 194/03, LEX nr 102907.

36 Under the provisions of the Directive, the moment when a lawyer is allowed to lawfully intervene comes, by principle, immediately after a person is informed of being suspected of committing a criminal offence. See: F. Gros, The EU directives on the rights of suspects. State of transposition by France, Eucrim. The European Criminal Law Associations 1 (2017), 29. February 3, 2020 - https://eucrim.eu/articles/state-transposition-france-eu-directives-rights-suspects.pdf.

37 See: M. Wąsek-Wiaderek, Dział I. Zasady ogólne, art. 4 In: Kodeks postępowania w sprawach o wykroczenia..., 19.

38 As rightly pointed out by S. Steinborn (Opinion of Poland's Criminal Law Codification Committee on the Transposition of EU Directive 2013/48/EU by Poland, issued 22 October 2013, p.6, online version accessed 29 December 2019 - https://www.gov.pl/web/ sprawiedliwosc/opinie-komisji-kodyfikacyjnej-prawa-karnego), "[...] it would be justified 
a detained person can exercise his or her right of access to a lawyer - as regulated by the provisions of Poland's Code of Procedure in Minor Offences - is questionable. Although the legislator does not determine the form of contact between the detainee and his or her lawyer (usually by telephone or e-mail), and obliges the investigative authorities to provide the detainee, upon request, with an opportunity to speak with his or her lawyer directly, it empowers the relevant authority to demand presence during the conversation between a detainee and his or her lawyer. It should be stressed that this concise, general provision laid down in Article 46 par. 4 of the Code of Procedure in Minor Offences is too authoritarian in nature, as it does not provide for differentiation of circumstances under which the presence of representatives of law enforcement authorities during a conversation between a detainee and his or her lawyer could be justified, and hence is also inconsistent with the guarantees contained in the Directive. Recital 33 of Directive 2013/48/EU makes it clear that confidentiality of communication between suspects or the accused and their lawyers is essential to ensure the effective exercise of the right of defence, which is part of the right to a fair trial. Hence, all Member States need to respect the principle of confidentiality of meetings and other forms of communication between a detainee and his or her lawyer ${ }^{39}$.

The provisions of Directive 2013/48/EU do not impose on Member States an obligation to provide free legal aid to materially deprived detainees. However, according to Recital 28 of the Directive, where suspects or the accused are deprived of their liberty, Member States should ensure that those persons are able to effectively exercise their right of access to a lawyer, including provision of due assistance of a lawyer for a person who does not have one. Recital 28 rules that under aforementioned circumstances, Member States are obliged to provide a detained person with a list of

- also in the context of the provisions of Directive 2013/48/EU - to postpone the moment of obtaining the procedural status of a suspect from the moment when the charges are presented to the moment when the procedural organ takes the first procedural step expressing its willingness to prosecute the person (e.g. detention) [...]".

39 The aim of Directive 2013/48/EU is therefore not only to allow access to a lawyer at the right time for the defence, but also to ensure appropriate quality of contact between a lawyer and his or her client. See: T. Koncewicz, A. Podolska, Dostęp do adwokata w postępowaniu karnym. O standardach i kontekście europejskim, Palestra 9 (2017), 12. 
lawyers to choose from, or, if necessary, may apply solutions for ex officio legal assistance.

The obligation of Member States to ensure that a detained person has access to a lawyer for ex officio legal assistance is laid down in Directive 2016/1919/EU of the European Parliament and of the Council of 26 October 2016 on legal aid for suspects and accused persons in criminal proceedings and for requested persons in European arrest warrant proceedings $^{40}$. Under Directive 2016/1919/EU, suspects and accused persons who are deprived of their liberty in criminal proceedings ${ }^{41}$ have the right to free legal assistance if they do not have sufficient resources to pay for the assistance of a lawyer ${ }^{42}$. This guarantee is not provided for by the provisions of Poland's Code of Procedure in Minor Offences. Article 4 of the Code fails to foresee the right of defence as defined under the Directive, which thwarts activation of the resulting effective application of the provisions regulating ex officio appointment of defence counsel ${ }^{43}$. The exclusion of a suspected person from the protection of the right of defence means that if he or she is detained, he or she has to bear the costs of a defence counsel.

\subsection{The right of a requested person and of a person specified} in Article 54 par. 6 of the Code of Procedure in Minor Offences of access to a defence counsel

Article 2(4) of Directive 2013/48/EU guarantees access to a lawyer for a requested person at the judicial stage of the proceedings for offences, as

40 OJ L 297/1, 4.11.16. The Legal Aid Directive is an important complement to the Access to a Lawyer Directive, as it allows people who lack the financial means to benefit from a defence counsel. The proximity of the regulation of the Legal Aid Directive to the content of the standards contained in the ECHR, to which all Member States are parties, makes it possible for the majority of Member States to accept the content of the Legal Aid Directive. See: S. Cras, "The directive on the right to legal aid in criminal and EAW proceedings. Genesis and description of the sixth instrument of the 2009 roadmap", Eucrim. The European Criminal Law Associations 1 (2017), pp. 43-44. February 3, 2020 - https:// eucrim.eu/articles/directive-right-legal-aid-criminal-and-eaw-proceedings/.pdf.

${ }_{41}$ Article 2(1)(a) of Directive 2016/1919/EU.

42 Article 4(4)(b) of Directive 2016/1919/EU.

${ }^{43}$ Article 4 par. 2 sentence 3 of the Code of Procedure in Minor Offences reads: "Regulations of Article 21-24 shall apply accordingly." 
well as for a person specified in Article 54 par. 6 of the Code of Procedure in Minor Offences at the stage of investigation. The provisions of this Directive, in so far as they correspond to rights guaranteed by the ECHR, should be implemented in a manner consistent with the provisions of the ECHR and in accordance with the judgments of the ECtHR (Recital 53). Therefore, the guarantees of a fair trial, including the right of self-defence or of a defence counsel, as expressed in Article 6(3) of the ECHR, apply to a requested person and to a person with respect to whom there are reasonable grounds for issuing a request of punishment. In assessing whether a case is a criminal matter, the ECtHR takes into account the criteria developed in its judgements: the classification of the charge in question under national law, the nature of the charge, and the severity of the sanction that can be adjudicated against the charged person ${ }^{44}$.

The Directive guarantees access to a lawyer to a person with respect to whom issuing a request of punishment as a result of his or her questioning, detention, identity parade, confrontation or procedural experiment is deemed reasonable ${ }^{45}$. The right of access to a lawyer in connection with the questioning is reflected in Article 4 par. 2 of the Code of Procedure in Minor Offences, according to which the right of defence, including the right to be assisted by a single lawyer, is vested in the person specified in Article 54 par. 6 of the Code of Procedure in Minor Offences and activated at the moment of his or her entering the questioning procedure, after being notified of the content of the charges, or when the person is summoned to submit a written explanation. The person needs to be informed of this right ${ }^{46}$. Article 4 par. 2 of the Code of Procedure in Minor Offences indicates the commencement of the questioning as the moment of activating an opportunity to exercise the right of defence. This means that a person with regard to whom there are justified grounds for drawing up a request of punishment may exercise his or her right of defence from the moment of notification of the content of the charge. This is because

44 See: M. Wąsek-Wiaderek, Dział I. Zasady ogólne, art. 4 [in:] Kodeks postępowania w sprawach o wykroczenia..., 17.

45 Ibid., 18.

46 The second sentence of Article 54 par. 6 of the Code of Procedure in Minor Offences also requires that a specified person be instructed about the right to refuse to provide explanations and about the right to submit evidence. 
Article 54 par. 6 of the Code of Procedure in Minor Offences rules that the notification of the content of the charge entered in the minutes of the questioning begins the very questioning procedure ${ }^{47}$.

It should be stressed, however, that the content of the charge against the person specified in Article 54 par. 6 of the Code of Procedure in Minor Offences may be modified at a later stage ${ }^{48}$. This is because proceedings for minor offences lack a regulation concerning the grounds for informing the aforementioned person about a change in the content of the charges or about their supplementation. Under such circumstances, a relevant regulation would enable undertaking the defence, as directly connected with the right to procedural information ${ }^{49}$. If the circumstances of the case prove that a person specified in Article 54 par. 6 of the Code of Procedure in Minor Offences committed an act whose formal specification differs from the original one, and the change is significant, as it concerns, e.g. the time or place of committing a prohibited act, or since it results from any other reason that affects the content of the charge, so that it may lead to a change in the manner of the defence, then the procedural authority should question that person again, after presenting the new content of the charge in order to enable him or her to defend effectively ${ }^{50}$. The doctrine

47 See: M. Wąsek-Wiaderek, Dział I. Zasady ogólne, art. 4, In: Kodeks postępowania w sprawach o wykroczenia..., 19

48 See: A. Sadło-Nowak, Dział VII. Czynności wyjaśniające, art. 54, In: Kodeks postępowania w sprawach o wykroczenia...., 310.

49 See: M. Kurowski, Komentarz do art. 314 k.p.k., In: Kodeks postępowania karnego, Tom I, Komentarz aktualizowany, ed. by D. Świecki, LEX/el. 2019, theses 1 and 2. As regards criminal proceedings, a parallel regulation is expressed in Article 314 of the Code of Criminal Procedure, which determines the grounds for issuing a decision to modify or supplement the charges. See: S. Steinborn, Komentarz do art. 314 k.p.k., In: ed. by S. Steinborn, Kodeks postępowania karnego. Komentarz do wybranych przepisów, LEX/el. 2016, thesis 1 .

50 It should be emphasised that this practice of procedural authorities is provided for by the legislator in the Regulation by the Minister of Justice of 7 April 2016, Rules of Internal Procedure for the Prosecution Offices. Pursuant to par. 141(2) of the Regulation, a decision to modify the charges shall be issued if there is a need to significantly change the description of an act, or if the alleged act should be qualified as belonging under a more severe legal regulation; under a regulation of an analogical severity of punishment; or, finally, under a regulation of a reduced severity of punishment, if any of these choices are relevant for the suspect's defence. This procedure may be applicable in proceedings for offences 
only contains postulates concerning the suggested manner of operation of the authorised bodies ${ }^{51}$ in the absence of a specific regulation in the Code of Procedure in Minor Offences, which may lead to a situation in which the right of defence of a person specified in Article 54 par. 6 of the Code of Procedure in Minor Offences will not be properly guaranteed, ${ }^{52}$ also from the perspective of the requirements of Directive 2013/48/EU. According to Article 3(3)(b) of the Directive, Member States are obliged to ensure that suspects or accused persons enjoy the right to the presence and effective participation of their lawyer during their questioning. The participation of a lawyer must comply with the procedures laid down in national law, provided that they are without prejudice to the relevant law and its substance. Undoubtedly, a person specified in Article 54 par. 6 the Code of Procedure in Minor Offences as well as his or her lawyer must be presented exact information about the charges if the lawyer is to undertake effective action during the questioning. Providing information about the charges underlies effective exercise of the right of defence and should therefore be guaranteed also in cases where - due to the change of factual or legal circumstances - the content of the charges needs modification.

Pursuant to the provisions of the Code of Procedure in Minor Offences, the requested person has the right of defence, including the right to be

when conducted by a prosecutor, who has a power to act at each stage of proceedings for offences, including the pre-trial stage. Article 56, par. 1 of the Code of Procedure in Minor Offences states that a prosecutor may carry out investigative actions specified in Article 54 of the Code of Procedure in Minor Offences. Whereas, pursuant to Article 18, par. 1 of the Code, a prosecutor can also submit a request of punishment in each offence, thus becoming a public prosecutor.

51 See: A. Skowron, Kontrowersje wokół czynności wyjaśniających w sprawach o wykroczenia (part 2), Paragraf na Drodze 8 (2004), 32.

52 Under the current legal regime in Poland, officers representing the authorities conducting the investigation are not obliged to repeat the questioning of a person specified in Article 54 par. 6 of the Code of Procedure in Minor Offences as a result of modifications of the charges. See: A. Sadło-Nowak, Dział VII. Czynności wyjaśniające, art. 54, In: Kodeks postępowania w sprawach o wykroczenia..., 312. It should also be noted that the authority most frequently intervening in offences is the Police, which, pursuant to Article 54 par. 1 of the Code of Procedure in Minor Offences, carries out investigative actions in order to determine whether there are grounds for requesting punishment and to effectively collect data necessary to draw up a relevant request. 
assisted by a single lawyer. This person should be informed of this right ${ }^{53}$. The provisions concerning obligatory defence (Article 21 of the Code of Procedure in Minor Offences), the appointment of an ex officio defence counsel (Articles 22 and 23 of the Code of Procedure in Minor Offences), as well as the issue of establishing a defence relationship (specified in Article 24 of the Code of Procedure in Minor Offences) also apply to a requested person and a person specified in Article 54 par. 6 of the Code of Procedure in Minor Offences ${ }^{54}$. The right to obligatory defence is vested in the persons with sight, hearing and speech impediments or in cases where a justified doubt occurs as to the suspect's sanity, in cases when he or she does not have a lawyer of their choice ${ }^{55}$.

54 par. 6 of the Code of Procedure in Minor Offences regulates an option to appoint a defence counsel ex officio in case of material depravation of the requested person. This requires the demonstration that persons having the right of defence are unable to bear the costs of the defence without a serious detriment to their own and their family subsistence, and that the participation of a lawyer in the case is necessary for the sake of a just trial. It is only when both conditions are met cumulatively that a lawyer can be appointed that is ex officio ${ }^{56}$. As regards the principle of access to ex officio legal aid, the provisions of the Code of Procedure in Minor Offences fulfil the guarantees of Directive 2016/1919/EU. Recital 13 of the Directive also gives Member States freedom to choose to provide free legal assistance to offenders, provided that the right to a fair trial is preserved, if the examination of legitimacy in their case would fail. Conversely, the criterion for assessing the justification for deprivation of liberty is applied differently. In this case, the criterion is always considered to be met under Article 4(4) of Directive 2016/1919/EU. The Directive does not require an examination of the severity of the offence, the complexity of the case, or the severity of the potential punishment in the case of deprivation of

53 Article 4 par. 1 of the Code of Procedure in Minor Offences.

54 The obligation of a proper application of Articles 21-24 of the Code of Procedure in Minor Offences results from Article 4 par. 2, sentence 3 of the Code of Procedure in Minor Offences.

55 Article 21 par. 1 and 4 of the Code of Procedure in Minor Offences.

56 See: post. SN (Supreme Court of Poland's Decision) of 16 November 2011; III KZ 77/11, OSNK 2012, no. 2, item 20. 
liberty ${ }^{57}$. On the other hand, in the case of detention of a person specified in Article 54 par. 6. of the Code of Procedure in Minor Offences, the provisions of the Code conditions granting of a ex officio lawyer on the cumulative fulfilment of two criteria indicated in Article 22 of the Code. Thus, in this respect, they are not consistent with the requirements of $\mathrm{Di}$ rective 2016/1919/EU.

When analysing the issue of effective access to an ex officio lawyer at the pre-trial stage in the procedure for offences, one should observe that the procedure currently in force may also raise doubts as to its compatibility with the guarantees under Directive 2013/48/EU. If a person specified in Article 54 par. 6 of the Code of Procedure in Minor Offences files an application for appointing a ex officio defence counsel, the body authorized for the investigation should request an investigative action on the part of the president of the court competent to hear the case or the relevant court registrar ${ }^{58}$. Pursuant to Art. 23 par. 2 of the Code of Procedure in Minor Offences, and in relation to Art. 81a par. 4 of the Code of Criminal Procedure, the procedure for appointing a defence counsel is regulated by the Regulation by the Minister of Justice of 27 May 2015 on the manner of ensuring that an accused person can use the assistance of a ex officio lawyer ${ }^{59}$. Pursuant to par. 11(3)(1) of this Regulation, if the circumstances indicate the necessity to immediately undertake the defence, the authority conducting the investigation is obliged to forward by fax an application for the appointment of a defence counsel funded by the public, along with the relevant documentation ${ }^{60}$ to the court competent to hear the case, with an added proviso that this action should be taken immediately after such an application is filed. However, the prompt fulfilment of this requirement by the investigating authority does not mean that the application can be immediately examined. In a situation where presenting the charges takes place in the afternoon or on weekend days, a chance for timely assistance

57 Article 4(4)(b) of Directive 2016/1919/EU.

58 Article 23 par. 1 of the Code of Procedure in Minor Offences.

59 Journal of Laws of 2017, item 53

6057 These documents need to be filed in order to prove that a person specified in 54 par. 6 of the Code of Procedure in Minor Offences is not able to bear the costs of defence without serious detriment to the necessary subsistence of himself or herself and his or her family. 
by an ex officio defence counsel is scarce. Moreover, the chance decreases when the proceedings are conducted outside the administrative area of the court competent to hear the case. The provisions regarding the appointment of a ex officio lawyer by the president of the court or the court registrar at the pre-trial stage of the proceedings constitutes a violation of the relevant legal guarantee, since it leads to the postponement of the moment of obtaining the assistance of a ex officio lawyer ${ }^{61}$, and it de facto prevents the effective exercise of the right of access to a lawyer, as guaranteed by Directive 2013/48/EU. In such circumstances, the Code should provide for the appointment of a ex officio defence counsel by the body conducting direct investigative actions - the police or the prosecutor - while the verification of potential prerequisites for the ex officio defence should take place after certain activities have been carried out ${ }^{62}$. Even in case of their non-fulfilment, there is an option to charge a person specified in Article 54 par. 6 of the Code of Procedure in Minor Offences with the costs of the ex officio assistance in case of conviction ${ }^{63}$.

\section{CONCLUSIONS}

The analysis of the possibility of exercising the right of access to a lawyer by the suspect and the passive party to the proceedings for offences unveils the fact that Poland's procedural regulations in force in this area do not always harmonise with the EU guarantees provided by Directives 2013/48/EU and 2016/1919/EU. The main idea in these regulations concerning the proceedings for offences is that they make it possible for the suspect to exercise his or her right of defence. The EU principle of access to a lawyer is only met when a suspect is detained, but with the exclusion made in the Code of Procedure in Minor Offences that under such circumstances a lawyer cannot perform as a defence counsel.

${ }^{61}$ See: S. Steiborn, Dostęp do obrońcy na wczesnym etapie postępowania karnego. Uwagi de lege lata i de lege ferenda, Europejski Przegląd Sądowy 1 (2019), 40.

62 Ibid., 40-41.

63 Article 119 par. 1 of the Code of Procedure in Minor Offences. 
This status quo results from discrepancies in how a suspect is defined for criminal proceedings under national and the EU law, which, consequently, leads to terminological discrepancies, stemming from divergent nomenclature use in Polish procedural law and in Directives 2013/48/EU and 2016/1919/EU. In Polish criminal trial, including proceedings for offences, presenting the charges is the moment when a suspected person is informed about a suspicion of his or her committing a prohibited act. No other action - even if it significantly affects the procedural situation of a suspected person - can be lawfully used to modify his or her status and, consequently, cannot activate the right of defence.

Therefore, the discrimination between a suspected person and a suspect in Polish criminal trial stands in the way of ensuring effective practical implementation of the guarantees laid out in Directive 2013/48/UE, as it leads to an implementation of EU guarantees with regard to a suspect, but to the prejudice of the rights of a suspected person. Consequently, the Code of Procedure in Minor Offences lacks a regulation which would guarantee a suspected person the right to a lawyer, despite the legal possibility to carry out specific procedural steps with his or her involvement, e.g. identity parade or detention. There is no doubt that a suspected person is in certain situations a subject of guarantees under both Directives. Therefore, it seems appropriate to introduce procedural changes, which would shift the activation of the right of access to a lawyer from the moment of the presentation of the charge to the moment when the procedural authority takes an action against a suspected person that constitutes an expression of the procedural authority's conviction that he or she has committed an offence.

An option to change the ex officio defence system so as to provide access to an ex officio defence counsel at the first stage of the criminal investigation, i.e. when a suspected person is detained or when he or she participates in identity parade, is also worth serious consideration. The EU requirement of effective access to an ex officio defence counsel encourages consideration of an appropriate statutory solution, whereby police and law enforcement authorities would have the power to grant temporary ex officio legal aid in cases where it is not possible to process an application for ex officio legal aid before an authorised body has heard the case, or before carrying out evidence examination, as indicated in Directive 2016/1919/ 
EU. Introducing of a procedure for a prompt appointment of an ex officio lawyer to a materially deprived detainee also calls for consideration, including the introduction of a system of on-call time for lawyers, on terms analogical to criminal procedure.

As for the confidentiality of contact of a client with a lawyer, as seen from the perspective of EU standards, an amendment is required in Article 46 par. 4 of the Code of Procedure in Minor Offences, which currently provides for the possibility of the procedural authority's presence during a conversation between a detainee and a lawyer, even though the aim of Directive 2013/48/EU is not only to ensure the detainee's effective access to a lawyer, but also to guarantee the appropriate quality of this contact. Introducing an appropriate mechanism to allow a detainee to obtain information about available lawyers that he or she could cooperate with is also a justified proposal. The practice of law enforcement authorities could consist in providing a detainee with an appropriate list of lawyers with their contact details and in assisting a detainee in establishing contact with the lawyer of his or her choice.

\section{REFERENCES}

Cras Steven, 2017. „The directive on the right to legal aid in criminal and EAW proceedings. Genesis and description of the sixth instrument of the 2009 roadmap", Eucrim. The European Criminal Law Associations' Forum 1: 34-45. Luty 3, 2020 - https://eucrim.eu/articles/directive-right-legal-aid-criminal-and-eaw-proceedings/.pdf.

Eichstaed Krzysztof, 2019. „Komentarz do art. 71 k.p.k.” In: Kodeks postępowania karnego, Tom I, Komentarz aktualizowany, ed. by. Dariusz Świecki, LEX/el.

Gądzik Zuzanna, 2015. „Komentarz do art. 15” In: Ustawa o Policji. Komentarz, Czebotar Łukasz, Gądzik Zuzanna, Łyżwa Aneta, Michałek Aneta, Świerczewska-Gąsiorowska Anna, Tokarski Mirosław, LEX/el. 2015, thesis 3.

Grabowska-Moroz Barbara (ed.) 2018. Prawo dostępu do obrońcy w świetle prawa europejskiego. Podręcznik. Warszawa 2018 - http://www.hfhr.pl/wp-content/uploads/2018/05/Prawo-dost\%C4\%99pu-do-obroncy-w-swietle-prawa-UE-FIN.pdf.

Gros Félix, 2017. „The EU directives on the rights of suspects. State of transposition by France", Eucrim. The European Criminal Law Associations’ Forum 1:27-30 
- https://eucrim.eu/articles/state-transposition-france-eu-directives-rights-suspects.pdf.

Klamczyńska Alicja, Ostropolski Tomasz, 2014. „Prawo do adwokata w dyrektywie 2013/48/UE - tło europejskie i implikacje dla polskiego ustawodawcy", Białostockie Studia Prawnicze 15: 143-163.

Koncewicz Tomasz, Podolska Anna, 2017. „Dostęp do adwokata w postępowaniu karnym. O standardach i kontekście europejskim”, Palestra 9: 9-23.

Kosonoga Jacek, 2018. „Dział VI, Środki przymusu, Rozdział 8, Zatrzymanie, Art. 46”. In: Kodeks postępowania w sprawach o wykroczenia. Komentarz, ed. by. Andrzej Sakowicz, 270-277. Warszawa: Wydawnictwo C.H.Beck.

Kurowski Michał, 2019. „Komentarz do art. 314 k.p.k.” In: Kodeks postępowania karnego, Tom I, Komentarz aktualizowany, ed. by. Dariusz Świecki, LEX/el.

Pączek Tomasz, 2005. „Pozycja prawna osoby podejrzanej o popełnienie wykroczenia w procesowym prawie wykroczeń", Policja 3: 45-48.

Sadło-Nowak Agnieszka, 2018. „Dział VII. Czynności wyjaśniające, art. 54”. In: Kodeks postępowania w sprawach o wykroczenia. Komentarz, ed. by. Andrzej Sakowicz, 298-324. Warszawa: Wydawnictwo C.H.Beck.

Skowron Andrzej, 2004. „Kontrowersje wokół czynności wyjaśniających w sprawach o wykroczenia (część 2)”, Paragraf na Drodze 8: 31-35.

Steinborn Sławomir, 2016. „Komentarz do art. 314 k.p.k.” In: Sławomir Steinborn (ed.), Kodeks postepowania karnego. Komentarz do wybranych przepisów, LEX/el.

Steinborn Sławomir, 2019. „Dostęp do obrońcy na wczesnym etapie postępowania karnego. Uwagi de lege lata i de lege ferenda”, Europejski Przegląd Sądowy 1: 38-46.

Światłowski Andrzej, 2018. „Dział I. Zasady ogólne, art. 1”. In: Kodeks postępowania w sprawach o wykroczenia. Komentarz, ed. by. Andrzej Sakowicz, 4-12. Warszawa: Wydawnictwo C.H. Beck.

Wąsek-Wiaderek Małgorzata, 2018. „Dział I. Zasady ogólne, art. 4”. In: Kodeks postępowania w sprawach o wykroczenia. Komentarz, ed. by. Andrzej Sakowicz, 16-21. Warszawa: Wydawnictwo C.H.Beck.

Wąsek-Wiaderek Małgorzata, 2019. „Dostęp do adwokata na wczesnym etapie postępowania karnego w prawie Unii Europejskiej”, Europejski Przegląd Sądowy 1: 17-23. 